\title{
GROUPWARE SEBAGAI SALAH SATU TEKNOLOGI INFORMASI UNTUK E- LEARNING (DISTANCE LEARNING)
}

\author{
Julisar \\ Information Systems Department, School of Information Systems, Binus University \\ Jl. K.H. Syahdan No. 9, Palmerah, Jakarta Barat 11480 \\ julisar_s@yahoo.com
}

\begin{abstract}
E-Learning is the process of distance learning by using of computer technology, computer network and/ or Internet. E-Learning is delivered by utilizing computing devices. With e-learning, lecture material can be distributed either on-line using a network connection as well as off-line using a mobile media. One type of software used in distance learning is Groupware. It is a software product to support a group of people who share a task or goal to work together to achieve that goal. Two types of groupware technology are Electronic Teleconferencing and Real-time Collaboration Tools. Electronic Teleconferencing is electronic communication technology that allows two or more people in different locations to simultaneously conduct the conference. In Video Conference, participants in a location can see the other participants who are in different locations.
\end{abstract}

Keywords: groupware, information technology, distance learning, e-learning

\begin{abstract}
ABSTRAK
E-Learning merupakan proses pembelajaran jarak jauh (distance learning) dengan memanfaatkan teknologi komputer, jaringan komputer dan/atau Internet. Melalui e-learning, materi perkuliahan dapat didistribusikan baik secara online menggunakan koneksi jaringan maupun offline menggunakan movable media. E-learning disampaikan dengan memanfaatkan perangkat komputer. Salah satu jenis perangkat komputer yang dipakai dalam distance learning yaitu Groupware. Groupware merupakan suatu produk peranti lunak yang mendukung sekumpulan orang yang berbagi tugas atau tujuan yang saling bekerjasama untuk mencapai tujuan tersebut. Dua tipe teknologi groupware yaitu Electronic Teleconferencing dan Real-time Collaboration Tools. Electronic Teleconferencing adalah teknologi komunikasi elektronik yang memungkinkan dua orang atau lebih di lokasi berbeda melakukan konferensi secara simultan. Dalam Video Conference, partisipan di satu lokasi dapat melihat partisipan lain yang berada di lokasi yang berbeda.
\end{abstract}

Kata kunci: groupware, teknologi informasi, distance learning, e-learning 


\section{PENDAHULUAN}

Pada metode pembelajaran konvensional, hubungan antara pelajar dan pengajar merupakan titik sentral proses pembelajaran. Dengan metode ini, proses pembelajaran dapat menghasilkan suatu kualitas yang baik bukan hanya nenjadikan peserta didik pandai melainkan juga mempunyai tingkah laku yang santun. Namun dengan kondisi yang ada sekarang ini, misalnya sarana dan prasana tidak sesuai dan semakin banyak peserta, maka metode konvensional kurang dapat menghasilkan kualitas yang diharapkan. Oleh karena itu perlu ada metode alternatif lain yang dapat menangani kondisi yang ada tadi yang tidak bergantung pada ruang dan waktu. Metode pembelajaran yang dapat digunakan adalah dengan E-Learning (distance learning).

Kemajuan teknologi sekarang ini memungkinkan sebagian orang melakukan proses pembelajaran tidak melalui tatap muka, tetapi dengan proses pembelajaran jarak jauh (distance learning). Hakekat e-learning (distance learning) adalah bentuk pembelajaran konvensional yang dituangkan dalam format digital melalui teknologi internet. Sistem ini dapat digunakan dalam pendidikan jarak jauh atau pendidikan konvensional. Oleh karena itu mengembangkan model ini tidak sekedar menyajikan materi pelajaran ke dalam internet tetapi perlu dipertimbangkan secara logis dan memegang prinsip proses pembelajaran. Begitu pula desain pengembangan yang sederhana, personal dan cepat, serta unsur hiburan akan menjadikan peserta didik betah belajar di depan internet seolaholah mereka belajar di depan kelas.

E-learning refers to learning supported by the Web. It can take place inside classroom as support to conventional teaching such as when students work on the Web during class. It also can take pale in virtual classroom, in which all course work is done online and classes do not meet face to face (Rainer, 2011). Dari definisi yang dituliskan oleh Rainer, dapat disimpulkan bahwa e-learning adalah pembelajaran jarak jauh (distance learning) yang memanfaatkan teknologi komputer, jaringan komputer dan/atau internet. E-learning memungkinkan pembelajar (mahasiswa) untuk belajar melalui komputer di tempat mereka masing-masing tanpa harus secara fisik pergi mengikuti pelajaran/perkuliahan di kelas. E-learning sering pula dipahami sebagai suatu bentuk pembelajaran berbasis web yang bisa diakses dari intranet jaringan lokal atau internet.

Greenlaw (1999) menuliskan bahwa Groupware is a generic term for network-based software designed to facilitate group activities such as discussions, debates, joint papers, or team projects. Groupware combines elements of Web pages, electronic bulletin boards, and discussion lists to create a shared hypermedia environment in which multiple users can read and edit each other's files synchronously or asynchronously. The market leader is Lotus NOTES, although a variety of other products are available. Pada dasarnya, sebuah groupware adalah sebuah aplikasi yang mampu menyatukan beberapa fasilitas ataupun kemampuan dari beberapa aplikasi independen dan menampilkannya dalam sebuah aplikasi yang lebih besar dan terintegrasi. Dengan adanya aplikasi groupware, tidak diperlukan banyak software yang diinstalasi, yang pada akhirnya juga bisa menghemat biaya lisensi (jika menggunakan aplikasi komersial) dan juga menghemat waktu, karena instalasi satu aplikasi sudah setara dengan menginstalasi beberapa aplikasi.

\section{METODE}

Metodologi peneltian yang dilakukan adalah dengan melakukan kajian literatur, observasi lapangan berdasarkan pengalaman penulis mengajar di Binus Online mata kuliah Konsep Sistem Informasi. 


\section{HASIL DAN PEMBAHASAN}

\section{Aplikasi Groupware untuk distance learning}

Sebuah sharing dari Steven A. Greenlaw, seorang Associate Professor dalam Bidang Ekonomi dari Mary Washington College, dalam Journal of Economics Education (1999) yang berjudul "Using Groupware to Enhance Teaching and Learning in Undergraduate Economics” adalah sebagai berikut:

An early use of groupware was distance learning. I discovered that forum could be used as a respectable substitute for me on the occasions when I was unable to meet classes. I designed a series of assignments that could be done inmy absence. That way, the interim period was not lost, and I could review the discussionwhen I returned. In principle, I could even participate in the discussionas long as I was able to dial in. These assignments in lieu of class were simply amoreconcentrated version of the type of electronic discussion that we carried onregularly; students readily participated. One semester, a student took my seminar,but because of a scheduling conflict, he was never able to attend a classmeeting. He did, however, participate in the electronic discussion, which hefound to be a workable alternative.Some groupware products support simultaneous reading and editing by multipleusers, allowing activities such as real time chat between participants. Although important for distance learning, such synchronous usage is unnecessaryfor my purposes. Moreover, asynchronous discussions tend to be at a highercognitive level than synchronous discussions.

Dari sharing yang dibagikan oleh Steven A. Greenlaw, dapat dilihat bahwa pemakaian groupware di dalam dunia pendidikan sangat membantu dalam proses pembelajaran. Dalam beberapa situasi, baik ketika Steven maupun mahasiswanya tidak dapat menghadiri perkuliahan yang terjadwal, proses pembelajaran tetap dapat dilaksanakan dengan memanfaatkan the electronic discussion. The electronic discussion ini merupakan suatu aplikasi Groupware yang mendukung simultaneous reading and editing dengan beberapa partisipan yang tergabung dalam proses pembelajaran yang terjadi secara real time.

\section{Manfaat Pemakaian Groupware}

Groupware memungkinkan mahasiswa dan dosen "menghilangkan” antara batas dan waktu dalam hal melakukan proses pembelajaran. Proses pembelajaran yang dilakukan dengan memakai Groupware ini dapat dilakukan di mana saja, misalnya di restaurant, café, taman di kampus dan dapat dilakukan kapan saja, bahkan tengah malam sekalipun proses pembelajaran dapat dilakukan. Dari pengalaman saya, lebih banyak mahasiswa yang membuat tugas-tugas mereka pada malam hari. Selain itu, sebagai bahan perbandingan dengan proses pembelajaran yang dilakukan secara tradisional, baik mahasiswa maupun dosen harus bertemu secara tatap muka dalam waktu dan tempat yang sama. Dengan pemakaian electronic discussion, mahasiswa bisa lebih mengekspresikan pendapat mereka. Dalam hal ini kuantitas dan kualitas mahasiswa yang aktif dalam diskusi dapat lebih ditingkatkan.

Yang jauh lebih penting dalam distance learning dengan pemakaian groupware ini adalah proses pembelajaran dari teacher-centered menjadi student-centered learning. Hal ini dapat dilihat dari dua pandangan, yaitu: (1) groupware menyediakan peralatan yang cukup baik, yaitu mahasiswa dapat belajar tanpa bantuan dari pengajar, hal ini membuat mahasiswa lebih mandiri di dalam mereka belajar. Dengan fasilitas electronic discussion, antar mahasiswa dapat saling berdiskusi, mengeluarkan pendapat dalam waktu yang tidak terbatas, yang kalau dalam proses pembelajaran tradisional terbatas dalam hal waktu dan ruang yang disediakan oleh kampus; (2) perubahan fokus yang terjadi dari cara pandang mahasiswa kepada pengajar yang awalnya sebagai single perspective, sekarang dapat menjadi multiple perspective. 
Sebuah sharing dari seorang mahasiswa di Amerika Serikat menyatakan sebagai berikut:

Being able to read and comment on other papers allowed me to see different viewson the same subject. Each perspective in itself taught me something. . . Furthermore, it helped me to explore my own understanding relative to others and then ask or answer questions about it. Seeing different perspectives in an interactive environment enabled everyone to learn.

Dari kedua hal tersebut di atas, bisa dilihat bahwa bentuk kerjasama dalam suatu grup memungkinkan para mahasiswa untuk dapat "saling membangun satu dengan yang lain dengan mengemukakan ide, pandangan mereka masing-masing dan dapat saling berdiskusi”. Keberadaan bentuk electronic discussion ini membuat ikatan yang kuat antara para mahasiswa dan meningkatkan motivasi mereka untuk dapat saling membantu satu dengan yang lain.

Dalam suatu bentuk diskusi yang diadakan di discussion forum, banyak mahasiswa yang "tanpa malu-malu” mengeluarkan ide-ide mereka, yang kalau dalam proses pembelajaran yang tradisional, mereka agak sungkan untuk mengeluarkan ide atau pemikiran mereka.

Manfaat yang dapat dirasakan dengan pemakaian distance learning, adalah: (1) proses pembelajaran yang berubah dari Teacher-centered Learning menjadi Student-centered Learning, yaitu mahasiswa menjadi yang aktif dalam proses pembelajaran, instruktur berperan sebagai mediator. Perubahan paradigma yang terjadi, kalau pada proses pembelajaran tradisional, mahasiswa menganggap instruktur dalam single perspective, sekarang menjadi multiple perspective; (2) mahasiswa dapat lebih berani mengungkapkan pendapat mereka. Karena mungkin ada di antara mahasiswa yang tidak berani mengeluarkan pendapat pada proses pembelajaran tradisional, karena mungkin mereka takut diejek atau ditertawakan oleh mahasiswa yang lain; (3) materi pembelajaran tidak terpusat pada materi yang sudah ditentukan saja, tetapi mahasiswa dapat memperluas pengetahuan mereka dari tugas-tugas dan diskusi yang diberikan oleh instruktur, maupun diskusi antar mahasiswa dengan memanfaatkan fasilitas electronic discussion; (4) proses pembelajaran tidak terikat oleh waktu dan tempat. Baik mahasiswa maupun instruktur dapat memperluas proses pembelajaran ini kapan saja dan di mana saja sesuai dengan kebutuhan dengan memanfaatkan jaringan yang tersedia selama 24 jam sehari, tujuh hari dalam seminggu.

\section{Biaya Pemakaian Groupware}

Suatu perbedaan yang penting antara proses pembelajaran dengan metode distance learning dan Tradisional adalah keberadaan instruktur, di mana peranan instruktur lebih banyak dibanding proses pembelajaran yang tradisional.Tugas-tugas instruktur antara lain, merancang penugasan untuk mahasiswa, mempersiapkan bahan-bahan diskusi khususnya pada saat sesi tidak bertatap muka dengan mahasiswa, membaca tugas-tugas mahasiswa dan memberikan komentar-komentar atas tugas yang dibuat oleh mahasiswa, menyediakan waktu untuk dapat berdiskusi dengan mahasiswa. Walaupun tugas-tugas tersebut bukan sesuatu yang sepele, tetapi seorang instruktur tidak seharusnya memaksa peserta didik untuk mengikuti kemauan instruktur karena peserta didik pada dasarnya akan mengikuti apa yang sudah digariskan oleh instruktur. Seorang instruktur juga diharapkan dapat menyediakan waktu yang lebih banyak untuk para peserta didik di luar waktu yang telah disepakati bersama.

Sesuatu yang tidak dapat dielakkan untuk proses pembelajaran dengan distance learning adalah keberadaan seperangkat piranti lunak (software) untuk mendukung proses pembelajaran. Keberadaan piranti lunak ini juga tidak lepas dari masalah-masalah yang mungkin timbul sehubungan dengan pemakaian piranti lunak ini. Biaya-biaya yang timbul karena masalah ini umumnya adalah biaya tetap (fixed cost), misalnya biaya pemeliharaan server. 
Pada awal pemakaian electronic discussion ini, banyak peserta didik yang mengalami kesulitan, karena mereka belum terbiasa menggunakan atau mengalami proses pembelajaran dengan model distance learning ini, tetapi perlahan tapi pasti, dalam minggu ke depan, banyak peserta didik yang sudah mahir menggunakan electronic discussion ini.

Dari tulisan di paragraf sebelumnya, dapat dilihat bahwa biaya yang terjadi antara lain: (1) waktu untuk mempersiapkan proses pembelajaran dengan distance learning lebih banyak. Ini merupakan intangible cost; (2) biaya pemeliharaan - entah dipergunakan atau tidak, biaya pemeliharaan ini akan tetap terjadi; (3) biaya pengadaan piranti lunak yang cukup tinggi untuk proses pembelajaran dengan distance learning. Selain piranti lunak, pengelola/penyelenggara proses pembelajaran dengan distance learning juga perlu mempersiapkan infrastuktur yang lain yang diperlukan untuk mendukung proses pembelajaran secara distance learning; (4) biaya pelatihan untuk mahasiswa yang baru pertama kali menggunakan piranti lunak untuk proses pembelajaran ini.Mahasiswa harus mempunyai motivasi yang cukup tinggi untuk mengikuti proses pembelajaran ini; (5) instruktur juga harus mengerti tentang pedagogi suatu materi ajar, sehingga materi ajar dapat dipahami/dimengerti oleh mahasiswa.

\section{PENUTUP}

Kemajuan Teknologi Informasi yang demikian pesat dewasa ini, dapat dimanfaatkan untuk beberapa segi kehidupan manusia. Salah satunya adalah memanfaatkan Teknologi Informasi dalam dunia pendidikan. Pemanfaatan Teknologi Informasi dalam dunia pendidikan dapat diterapkan melalui sistem pembelajaran yang baru yang disebut dengan distance learning.

Dengan pemakaian distance learning, dapat diperoleh beberapa manfaat, antara lain: (1) proses pembelajaran dapat dilakukan kapan saja dalam waktu 24 jam sehari, tujuh hari seminggu dan di mana saja, dapat dilakukan di cafe, taman umum, restaurant dan lain-lain yang menyediakan fasilitas hot-spot untuk dapat berselancar di dunia maya; (2) paradigma proses pembelajaran yang berubah dari teacher-centered learning menjadi student-centered learning. Dalam perubahan paradigma ini, peserta didik tidak hanya mengandalkan instruktur untuk belajar tetapi juga dapat memperluas wawasan dengan belajar secara mandiri dan bertanggung jawab terhadap proses pembelajarannya. Instruktur berperan sebagai mediator; (3) dapat menjangkau wilayah geografis lebih luas. Bagi mahasiswa yang berada di luar tempat pusat pembelajaran, mereka tetap dapat mengikuti proses pembelajaran yang dapat diakses melalui jaringan; (4) mahasiswa dapat lebih "mengekspresikan" dirinya ketika terjadi diskusi yang dilakukan di discussion forum. Mahasiswa yang mungkin punya sifat pemalu, mereka akan menjadi lebih berani untuk mengungkapkan idenya, berani berdebat dengan peserta didik yang lain.

Selain manfaat yang dapat dirasakan, ada juga kekurangan yang masih dapat terjadi sehubungan pemanfaatan teknologi informasi ini, yaitu: (1) instruktur harus mempersiapkan bahan yang menarik, supaya para mahasiswa dapat termotivasi untuk mengikuti proses pembelajaran. Butuh usaha yang cukup untuk mendesain bahan ajar sehingga menjadi bahan ajar yang menarik minat peserta didik. Mahasiswa harus "dibangunkan" motivasinya; (2) instruktur harus memahami pedagogi dari suatu materi ajar. Karena proses pembelajaran ini keterlibatan instruktur cukup minimal, oleh karena itu cara mengemas materi perlu diperhatikan sehingga mahasiswa dapat memahami materi tersebut ketika mahasiswa belajar secara mandiri; (3) biaya pemeliharaan yang cukup tinggi. Biaya pemeliharaan ini digunakan untuk tetap menjaga supaya server yang ada di tempat penyelenggara proses pembelajaran tetap dapat digunakan selama 24 jam sehari, tujuh hari seminggu; (4) biaya pengadaan piranti lunak yang cukup tinggi serta infrastruktur yang lain yang dibutuhkan untuk mengadakan proses pembelajaran secara distance learning. 


\section{DAFTAR PUSTAKA}

Greenlaw, Steven A. (1999). Using groupware to enhance teaching and learning in undergraduate economics. Journal of Economic Education.

Rainer, Kelly R, Jr; Casey G. Cegielski. (2011). Introduction to Information Systems: Enabling and Transforming Business. International Student Version. (3rd ed.). New Jersey: John Wiley \& Sons. 